\title{
The tragedy of state education in England: Reluctance, compromise and muddle- a system in disarray
}

\author{
Sir John Cass's Foundation Lecture \\ read 7 March 2018 \\ STEPHEN J. BALL \\ Fellow of the Academy
}

Abstract: This paper is a reflection on the current state of education and education policy in England drawn from over forty years of my involvement in education policy research. It articulates a strong sense of my discomfort, disappointment, and frustration with the current state of the English education system and with the educational state. I shall take stock and look across the school system, confining myself to compulsory education, and argue that there is no 'system' at all. Rather, I suggest, the current iteration of school reform perpetuates and exacerbates the messiness and incoherence, and the mix of meddlesomeness and reluctance, that have always bedevilled education policy in England and at the same time reproduces and legitimates complex social divisions and inequalities embedded in this messiness. I also look back at the several attempts to impose some sort of order on the delivery of schooling (1870, 1902, 1944, 1988, and 2016) and the discordant interests that have confounded these attempts, particularly in relation to church schools.

Keywords: Incoherence, social divisions, church schools, the educational state, deconcentration.

This paper is a reflection on the current incoherent state of education and education policy in England. It articulates a strong sense of my discomfort, disappointment, and frustration with the state of the English school system, or rather the lack of system, and with the educational state itself. I will look back at the several attempts to impose some sort of order on the delivery of schooling (1870, 1902, 1944, 1988, and 2016) and the discordant interests that have confounded these attempts, particularly in relation to church schools, and the ways in which an absence of order both reflects the political rationality of a reluctant state and facilitates and reproduces, sometimes 
obscurely, sometimes crudely, various forms of social cleavage. In reviewing how things stand now, I will describe the different types of schools currently in play and their uneven distribution, patterns of access, and levels of performance. I will rehearse various sorts of evidence related to access, opportunity, and performance and signal some of the inefficacies, untoward consequences, and absurdities of those unevenesses.

As indicated and as I shall try to make clear, to call the school system a system suggests more coherence than is deserved. Rather than a system we have, and have had since its inception, a rickety, divided, unstable, and often ineffective, but nonetheless overbearing, educational apparatus. This apparatus is currently held tenuously together by a regime of testing and league table reporting that puts pressure on schools, through a mechanism that its prime advocate, Michael Barber, calls deliverology (Barber 2007: 42), in relation to which schools are incited to compete with one another to drive up student performance and extract maximum outcome value from students. This is the basis for what coherence there is, a form of performance management derived from business practices rather than educational principles. Measured outcomes pre-empt the purpose and values of education.

Most policy analysis work begins with an assumption of or brings to bear a perspective of coherence or rationality or planned order, and in this sense analysis often works to constitute the object of its concern. We lack the tools, and perhaps also the predilection, to address policy as incoherent or absurd (Webb 2014). While there are clearly some aspects of different political rationalities embedded in the making of English education policy and history, these do not work through to or produce sense and logic at the level of practice (Ball 1997). Rather they mix, meld, grate, and contradict to realise and perpetuate what Jenny Ozga calls 'ad hocery, serendipity, muddle and negotiation' (1990: 360), that now and always have bedevilled education policy in England. ${ }^{1}$ Nonetheless, I also consider or at least signal some political preoccupations and structural inequalities that underpin this messy apparatus, and historically constitute and reproduce its messiness. I shall thus attempt to run two separate but related theses together, with all the dangers of confusion that that portends - one focused on contingency and the other on continuity. It is difficult in a short paper to convey the scale and scope of the incoherence and disarray of current education policy and provision - if incoherence can have scale and scope. I must limit myself to some examples, snippets, and glimpses of an apparatus lurching from one prejudice, 'solution', or 'good idea' to the next without any explicit consideration of why and what for.

\footnotetext{
${ }^{1}$ Although Ozga is critical of policy analysis work that begins from a concern with ad hocery, inasmuch as it can lead to a failure to address the structural power relations that are invested in the policy process. I hope that is not the case here.
} 
In terms of the relation between education and the state, in all of this I argue that the state has both interfered too much and not enough. That is to say, governments have interfered at the wrong times for the wrong reasons, and been indecisive when they should have been clear and positive. In other words, the history of education policy is a mixture of reluctance, meddlesomeness, and muddle. To begin to explain this, first, I will attempt to demonstrate that both interference and indecision are fundamental characteristics of the history of education policy in this country: and, second, that education policy has little to do with education per se, but rather to do with the problems of the state itself. Neither point is novel, but they raise issues that are normally conveniently ignored in the policy process, with the result that we mistake political decisions for educational ones and education policy becomes mired in compromises and consequences driven by other issues - most repeatedly the issue of church schools and, in relation to that and more generally, the social interests of the elite and the middle class. The combination of meddlesomeness and muddle with these 'other' issues has conspired, and indeed it is tempting to say is intended, to reproduce a system that is riven with social divisions of many kinds. That is to say, it 'allows for' the assertion of social advantage and perpetuates inequality.

\section{IT DEPENDS ON WHERE YOU LIVE}

In the current arrangements for education in England - and to be very clear it is only England I am talking about here, not Scotland, Wales, or Northern Ireland - the sort of school your child may attend and their experience of education depend on where you live. Regional and local variations in access to schools of different types are stark and are a legacy of the politics of education that articulated and delimited the starting points of mass state education in the 19th century, compounded in recent times by the reforming zeal of each of the governments since 1988 and by a period of undirected and uneven local school reform (or its absence) in the period between 1944 and 1988. England has never had a universal system of state education worthy of that description but rather a set of competing subsystems that jostle, grate, and overlap.

Currently there are several different types of school:

- academies

- free schools

- grammar and secondary modern schools

- comprehensive schools

- community schools

- trust schools 
- special schools

- church schools of many faiths (voluntary controlled or voluntary aided, some of which are academies or free schools)

- studio schools

- university technical colleges (UTCs)

Some of these categories overlap: for example, some special schools are now academies; church schools maybe academies or community schools; most grammar schools (140 out of 163) are now academies. Furthermore, some previously independent private schools have recently entered the state system as academies and some other independent private schools act as academy sponsors.

The news emerged in the week that Ofsted chief inspector Sir Michael Wilshaw accused elite independent schools of only offering state education the 'crumbs off your tables'.

Sir Michael called on them to challenge the perception that they 'don't really care about the educational world beyond [their] cloisters and quads'. Last month another leading independent school, Wellington College, put on hold plans to create a chain of state-funded schools after a sharp fall in exam results at its flagship academy, which triggered the departure of its head.

(Times Educational Supplement (TES), 4 October 2013)²

Free schools and academies include sponsored and converter academies, some of which are new build; others are takeovers of 'failing' schools, some of which are enforced. However, it turns out that it is not always easy to find sponsors for the latter schools. Some sponsors prefer not to take on schools that are too challenging, despite the fact that the academies programme was conceived as a mechanism to bring new actors with different skills and capabilities into the education system to deal with the problem of underperforming schools.

Last month, it was reported that another major sponsor in the north of England, Wakefield City Academies Trust, is to pull out of running Hanson school in Bradford, after a 12-month trial. Hanson failed an Ofsted inspection in 2011-12 and has been without a permanent sponsor for five years.

In Lewisham, south London, plans for a trust to take on Sedgehill School this year have been put back until early 2018 as no sponsor has been found. Sedgehill failed an Ofsted last May.

(BBC News, 10 April 2018) $)^{3}$

A top public school is pulling out of its position as lead sponsor of an academy in one of England's most deprived areas, TES can reveal.

\footnotetext{
${ }^{2}$ https://www.tes.com/news/dulwich-college-pulls-out-academy-sponsorship

${ }^{3}$ http://www.bbc.co.uk/news/uk-england-leeds-43713057
} 
Dulwich College is to step down from the role at the troubled Isle of Sheppey Academy, Kent, in January to make way for the Oasis academy chain after admitting its staff were not equipped to help pupils at the state comprehensive.

(TES, 4 October 2013) ${ }^{4}$

This reluctance to take on difficult schools is a concern raised in a National Audit Office (NAO) report published in February 2018. The report also concludes with some comments that gesture towards a recognition of the sort of systemic disarray I am suggesting here.

There is substantial variation across the country, in the relative proportions of maintained schools and academies and in the availability and capacity of sponsors to support schools most in need. This complicated position means that it is incumbent on the Department to clarify its policy and make sure that the school system is coherent with all of its parts working effectively together. This will be crucial to secure value for money and provide children with access to good end-to-end schooling. ${ }^{5}$

The tenor of the second sentence would suggest that the NAO takes the view that there is currently an absence of clarity and coherence in Department for Education (DfE) policy. Pointing to another aspect of incoherence, the report also notes that 242 academies are located more than 50 miles from the head office of their sponsoring body. Following the publication of the report, the House of Commons Public Accounts Committee (PAC) announced an enquiry into the funding of academy conversion during which:

The Committee will ask representatives from the DfE whether conversions to academy schools deliver the right results for students and taxpayers, how they are addressing regional differences, and what they will do to ensure more conversion is better rolled out to underperforming schools. ${ }^{6}$

Academies may be free standing or part of a multi-academy trust (MAT). There are still local authority (LA) community schools, and among these we still have comprehensive schools. The Times still runs a comprehensive school of the year competition - in 2017, 1063 schools applied to this and Cardinal Vaughn School in London was the winner. There are also trust schools and foundation schools and special schools. There are grammar schools in eight areas of the countryBuckinghamshire, Rugby and Stratford districts of Warwickshire, the Salisbury district of Wiltshire, and most of Lincolnshire, Kent, Reading, and Medway - and thus in effect secondary modern schools in those areas. There are church schools of a

\footnotetext{
${ }^{4} \mathrm{https} / / / \mathrm{www} \cdot$ tes.com/news/dulwich-college-pulls-out-academy-sponsorship

${ }^{5}$ https://www.nao.org.uk/report/converting-maintained-schools-to-academies/

${ }^{6} \mathrm{https} / / / \mathrm{www}$.parliament.uk/business/committees/committees-a-z/commons-select/public-accountscommittee/inquiries/parliament-2017/converting-schools-academies-17-19/
} 
wide variety of kinds and denominations, some of which are voluntary aided and some voluntary controlled (see below). There are also studio schools and UTCs (the brainchild of ex-Secretary of State for Education Kenneth Baker). As of May 2017, 77 per cent of primary schools and 31 per cent of secondary schools remained as community schools; 4 per cent of primary schools and 26 per cent of secondary schools were free-standing academies; 18 per cent of primary schools and 36 per cent of secondary schools were part of MATs; 1 per cent of primary schools and 7 per cent of secondary schools were free schools (or studio schools or UTCs).

The UTC programme as a whole is sponsored by the Baker Dearing Educational Trust, established by Lord Baker and further supported by the Edge Foundation, the Gatsby Charitable Foundation, and the Garfield Weston Foundation. Many large companies have pledged to co-sponsor UTCs, including Arup, British Airways, Ford, Jaguar, Land Rover, and Sony. UTCs are an example of meddling and messiness. By November 2016, 36 such schools had opened and three more were planned. In October 2016, the then Secretary of State Justine Greening reiterated the Conservative government's support for UTCs.

We've made some great steps forward on our academic route over the last six years, but this is about diversity and choice. UTCs are about providing options for the many young people who want to pursue a route in their education that's more technical in nature, and UTCs can be a big part of how we do that.

(speech during visit to Didcot UTC, 17 October 2016 by then Secretary of State for Education Justine Greening) ${ }^{7}$

In the same year, seven UTCs were closed and another three that had been planned did not open, in most cases because of poor recruitment or poor examination performance, and in February 2017 Michael Gove (ex-Secretary of State for Education) wrote that the UTC idea 'has not worked' and that they had 'become a destination for underperforming children' ${ }^{8}$ In January 2017, Prime Minister Teresa May announced the funding of 'prestigious' institutes of technology, as part of her industrial strategy for post-Brexit. This is to include specialist mathematics schools based on the free school model. She referred to these initiatives as expressing a 'parity of aspiration', echoing the tripartite notion of 'parity of esteem'.

To reiterate, despite the articulation of the arrangements for schooling as based on the principle of parental choice (Allen et al. 2104), the possibility of choice of (or more accurately the expression of a preference) among these different sorts of schools depends on where you live. So, for example, in spite of the growth of the free school programme since 2011, two thirds of areas in England are not within a reasonable 
distance of either a primary or secondary free school. Alongside all of this: nearly 30,000 children were educated at home in the 2016/17 academic year. This represents a 97 per cent increase since 2011.

These various sorts of schools are subject to different regulations and funding arrangements and are variously run by different organisations, participants, and sponsors. Academies and free schools ${ }^{9}$ may be run by educational charities, universities, community groups, faith groups, parents groups, other existing schools, businesses, or private schools. The most recent iteration of the list (15 March 2018) of governmentapproved academy sponsors names 1,100 such sponsors.

Maintained schools - where funding and oversight are through the LA - are mostly either community schools (where the LA employs the school's staff and is responsible for admissions) or foundation schools, where the school employs the staff and has responsibility for admissions. The number of maintained schools is continually reducing as schools succumb to the temptations of academisation and the promise of absolute control over their budgets. One consequence of this attrition is that LAs find it increasingly difficult to carry out their remaining legal responsibilities-for example, for excluded and for looked-after children. It also means an absence of local planning oversight and as a result uneven patterns of over- and underprovision.

Most non-maintained schools act as their own admissions authorities. Thus, non-LA schools operate with diverse forms of recruitment and restrictions on recruitment - within a code of practice - overseen by the Schools Adjudicator. The most recent report of the Office of the Schools Adjudicator (8 February 2018) notes that their data shows:

That while 686 sets of admission arrangements were queried across 63 local authority areas, 414 of those queries were raised by just seven local authorities. The adjudicator considers 'that it is likely that in some parts of the country local authorities do not scrutinise arrangements adequately. ${ }^{10}$

The issue of school admissions is particularly fraught, obscure, and messy in relation to church schools, and a recent report: Mixed Signals: The Discrepancy Between What the Church Preaches and What it Practises About Religious Selection at its State-funded Schools produced by the Accord Coalition for Inclusive Education on behalf of the Fair Admissions Campaign, ${ }^{11}$ found that many Church of England schools that set their own admission arrangements continued to operate a religiously

\footnotetext{
${ }^{9}$ In order to open a free school, the proposing group must form a company limited by guarantee and choose members and directors to run it. Free school companies must use the DfE model memorandum and articles of association, meaning that once constituted the company will be an academy trust. ${ }^{10} \mathrm{https} / / /$ www.gov.uk/government/news/annual-report-of-the-chief-schools-adjudicator-for-england--3 ${ }^{11}$ https://drive.google.com/file/d/1i5ImrZIpgoFkC7QrkRUdr1tTvCruqhHe/view
} 
selective policy, while national Church guidance failed to recommend that schools should refrain from religious selection. Only one in eight Church of England dioceses advise their state-funded schools to not select pupils by faith. Many schools (and 50 per cent of the secondary schools) in even these notionally inclusive dioceses still operate a religiously selective admissions policy. In September 2016, the government announced its intention to relax existing rules on how faith schools select pupils, to allow new Catholic schools to open in England.

And a source from 10 Downing Street said at the time that the admissions cap, which limits oversubscribed new faith schools to only selecting half of their intake by reference to faith, had failed.

(BBC News, 9 September 2016 ${ }^{12}$ )

In January 2018, and perhaps not unrelatedly, Justine Greening ${ }^{13}$ (the only Secretary of Sate thus far in English educational history to have attended a comprehensive school) resigned and was replaced with a Catholic supporter of faith schools, Damian Hinds.

Damian Hinds, the Member of Parliament for East Hampshire, was educated at St Ambrose College, a Catholic grammar school in Cheshire, before attending Oxford University. He is a long-time supporter of faith schools.

The Catholic Church in England will likely welcome his appointment, after his predecessor refused to remove the admissions cap, which effectively prevents the Church from opening new schools.

(Catholic Herald 9 January 2018) ${ }^{14}$

All of the sorts of schools noted above are subject to Ofsted inspection-but more or less often depending on their grading. These inspections take place alongside the apparatus of oversight and control of schools, as noted previously, that is framed and driven by a regime of national and local league tables based on test and examination performance. This form of performance management enables the government to 'steer at a distance'. That is to say, ministers can exercise some degree of direction over the system through target and benchmark setting and in relation to changes in the key performance indicators.

As well as the residual LAs, there are also National and Regional Schools Commissioners (RSCs) appointed by the Secretary of State for Education and

\footnotetext{
${ }^{12} \mathrm{http} / / / w w w . b b c . c o . u k /$ news/uk-politics-37314149

${ }^{13}$ A Tory MP, speaking anonymously, told The Guardian it was a 'dreadful error to let her go', adding: 'May gives in to the boys but effectively sacks a woman born and raised in Rotherham, who went to the local comprehensive, who is bright and more than able, and who won a marginal seat beating Labouroh, and she happens to be in a same sex relationship.' (https://www.theguardian.com/politics/2018/jan/08/ theresa-mays-reshuffle-thrown-off-course-by-defiant-ministers)

${ }^{14} \mathrm{http}: / /$ catholicherald.co.uk/news/2018/01/09/church-school-supporter-is-new-education-secretary/
} 
regional boards, elected by local academy headteachers. RSCs were established in September 2014 with the responsibility for deciding which applications for academies would be taken forward, monitoring academy performance, and also for taking action when an academy is underperforming. They are also meant to champion academy freedoms. Their role has since been expanded to include tackling underperformance in LA schools. They are also responsible for deciding what action should be taken about academies and LA-maintained schools that are identified by the government as 'coasting'. The regions covered by the commissioners do not coincide with other administrative divisions (see Figure 1).

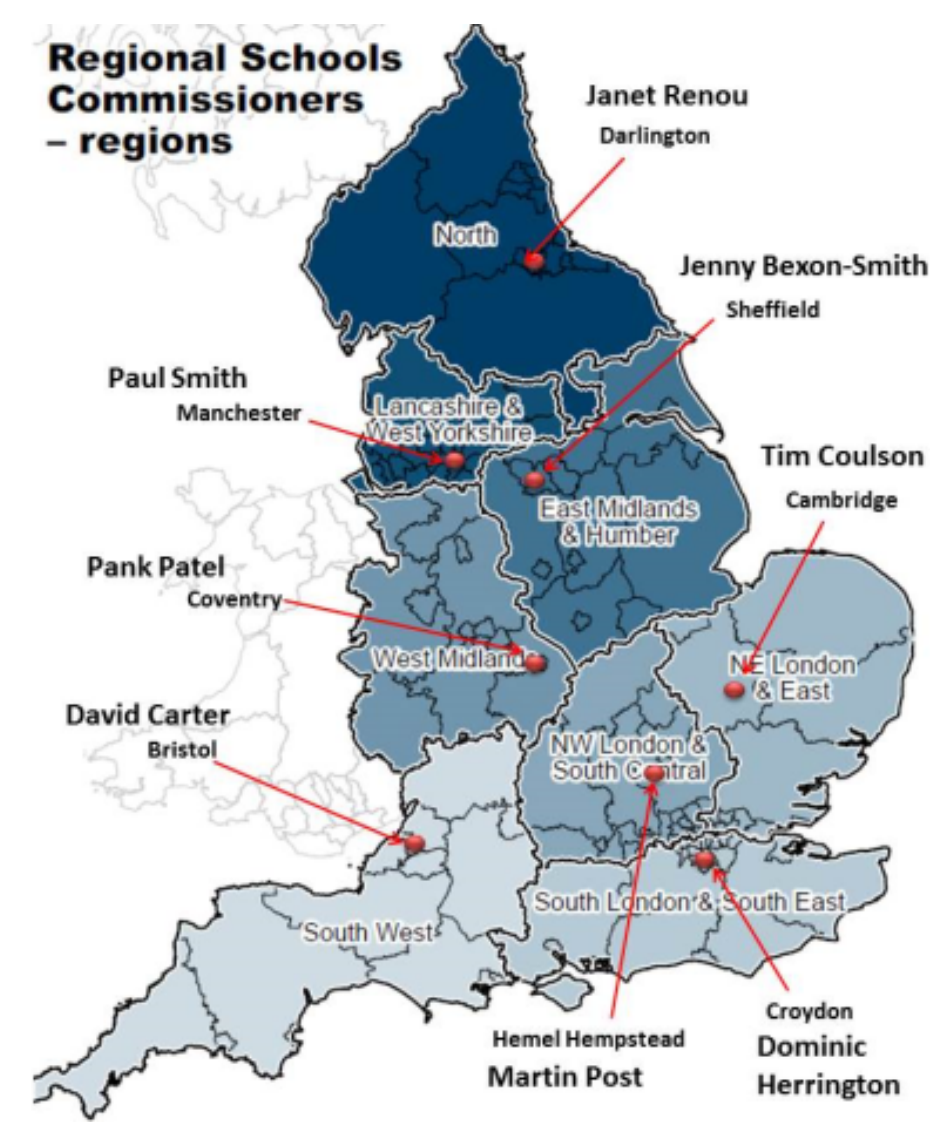

Figure 1. Regional Schools Commissioners. 
The RSCs face very different situations in terms of the number of existing academies and underperforming LA schools in their regions and, as noted above, the availability of sponsors for underperforming schools varies considerably across the country. The RSCs mark a further move in the almost total displacement of LAs from education policy responsibility while mimicking some of their previous roles.

In all of this, then, we have plenty of evidence of both what Skelcher calls the 'appointed' state (Skelcher 1998) - that is, the transfer of power from democratically accountable central and local government to quangos, commissioners, and sponsors who are appointed or approached or approved rather than elected-and the 'congested' state (Skelcher 2000) - a plural, and fragmented array of diverse providers, contractors, and agencies, set within a plethora of mediating partnerships. Much of this array - its management, ownership, and relations - is occluded or opaque and differentially effective (see Ball \& Junemann 2012).

\section{LITTERED WITH HISTORY}

I will return to the current state of education below, but I now want to establish some of the historical basis of the fragmentation and incoherence I have begun to describe and also suggest some ways in which, despite or because of the ferment of recent reform, the current apparatus of education bears various resemblances to that which existed prior to 1870 .

Until 1870, elementary schooling was left almost entirely to 'dame schools', church societies, and other voluntary organisations, and the funding came from a wide variety of philanthropic groups, including merchants and clergy (Mitch 2016). A 'system' of education began to emerge during the early 19 th century, in partial, halting, and reluctant fashion. Elementary schooling provision came to rest primarily on the efforts of the Church of England (The National Society for Promoting the Education of the Poor in the Principles of the Established Church), Nonconformist (British and Foreign School Society, Wesleyan Education Committee), and Catholic (Catholic Poor School Committee) school societies, and other voluntary and informal arrangements. From 1833 , the government began to pay annual grants to the societies. In 1818, just 7 per cent of children attended a day school and further growth was slow, although faster than that of the population. By 1870, about 700,000 six- to ten-year-olds were in schools, while about one million were not (Timmins 2001: 68). From 1870 on, the existing church schools were supplemented by, and then later incorporated into, the state school board system (see below). The board schools were established to 'fill the gaps' not served by the existing church schools. Timmins, referring to the 1944 Education Act (2001: 67), suggests that in 1870, 'by opting to subsidise church schools rather 
than create secular state ones, Parliament invested in a problem Butler [see below] would still be grappling with more than a century later.' The 1870 Act allowed for state funding of 50 per cent of the running costs of voluntary church schools. The National Society responded by raising $£ 10$ million and almost doubling the number of its schools to 12,000 in the next fifteen years.

Behind all this, the work of three Education Commissions formed the basis for what Simon (1994) called 'the emergent system' along the lines of social class. The Newcastle Commission 1861 dealt with elementary schools; the Schools Inquiry Commission 1868 (Taunton Commission) with grammar and endowed schools, and the Clarendon Commission 1864 with public schools. Best and Andrew (1972: 147) characterise 19th-century education policy as deliberately patterned to perpetuate class differences, magnifying 'its structure in detail'. Perkin describes this as putting 'education in a straightjacket of class' (Perkin 1969: 302) and Tawney (1931: 142) wrote that 'the hereditary curse of English education has been its organization along the lines of social class'.

It is difficult to understand the slow progress towards a free, state-provided system in 19th-century England until we grasp that education had long been regarded as a family decision, an issue of freedom from the state. Furthermore, its provision by deeply antagonistic, powerful denominational groups ensured that state interference was resisted until regulation became an urgent matter of both social control (related to electoral reform) and necessary economic improvement that philanthropy was failing to meet. The 1870 Act was not a progressive reforming measure, but rather a political rearguard action, a compromise with voluntarism, going against the grain of 19th-century liberal political thought:

The very complexity of the new social and economic environment and the comparative caution of the mid-Victorian elites meant that comprehensive and drastic solutions rarely seemed attractive let alone plausible.

(Hoppen 1998: 91)

The 1870 Act left the administration of schooling and the building of new state schools to local school boards which ran 3,692 schools by 1883, although by 1902 , voluntary elementary schools - church schools - still outnumbered state schools twoto-one. Which sort of school you might attend depended on where you lived. Compulsion was not introduced into this mix (for 5- to 10-year-olds) until 1881, while provision for 10- to 14-year-olds differed widely around the country - the possibility of access to school for 10-year-olds depended very much on where they lived. Fees were not abolished until 1891, a move viewed with alarm by many politicians and commentators. Indeed, introducing the 1870 Bill, W. E. Forster had argued that providing the full cost of elementary education would be 'not only be unnecessary but 
mischievous' and that the Act rested on the principle of 'sparing public money where it can be done without'.

Despite these halting, resentful, incoherent moves towards the mass provision of schooling, it was not until 1970 that the basis for universal access was legally established in England, when Margaret Thatcher, Secretary of State for Education, announced:

On 1 April, local education authorities became responsible for the education of severely handicapped children hitherto considered to be 'unsuitable for education at school'. Now for the first time in history all children without exception are within the scope of the educational system. The Education (Handicapped Children) Act of 1970 is the last milestone - along the road starting with the Education Act of 1870, which set out to establish a national system of education..$^{15}$

The local democratic and radical glimmerings that were represented by the directly elected but unwieldy system of 2,500 school boards were snuffed out by their abolition in 1902 and the responsibility for the provision and management of education was passed to LAs as part of a unification of the control of schooling. A Board of Education was also established for the first time as a government department by the 1902 Act and Welsh education began to diverge from the English system of provision at this point. While the 1870 Act had taken 28 days to debate, the 1902 Act took 59 days, and most of that time was spent not on issues of education but on the religious clauses. The new local education authorities (LEAs) were given authority over the secular curriculum of voluntary (church) schools. They provided grants for school maintenance, but if a school wanted to provide denominational teaching, the buildings had to be paid for by the church.

Versions of the 19th-century tiered and classed model of education continued up to the Second World War, by which time it could no longer contain and satisfy the aspirations of the growing middle classes, nor be electorally defended either on economic grounds or in terms of fairness and equity. By 1938, 88 per cent of children were attending 'all-age' schools up to the age of 14 . However, classes of 50 or more were not unusual and only one in 150 of these children ended up at university. A small, mainly lower-middle-class, group were selected at the age of 11 for 'special places' at LA secondary schools in which 45 per cent of places were free. Still smaller middleand upper-class groups attended various independent grammar schools, private schools, or public schools. Schooling continued to reflect the gradations of societyonly one in seven children remained at school after the age of 13, the intake to grammar schools increased only slightly from 90,000 in 1921 to 98,000 in 1938. Barnett (1986) called this a 'half-cock' education system and the figures for secondary

\footnotetext{
${ }^{15}$ www.margaretthatcher.org/document/102105
} 
participation compared poorly not only with Germany, France, and the US, but also with Scotland and Wales.

In relation to all of this, the 1938 Spens Committee (on Secondary Education), which established the basis for the 1944 Education Act, set aside a considerable amount of evidence that favoured the establishing of a single, multilateral secondary school system and, despite the adoption in 1942 of a Labour Party Conference motion to establish 'multilateral' schools, experiments with them were discouraged by the post-war Labour government and 'tripartitism' prevailed - a system of grammar, secondary modern, and technical schools (three types of school, and three types of curricula for three types of mind as the Norwood Report put $\left.\mathrm{it}^{16}\right)$. However, only 52 LEAs ever established technical schools. Access to grammar schools was based on the 11 plus - a general test for intelligence similar to an IQ test, but with the addition of testing for taught curriculum skills. The sort of secondary school your child might attend depended on where you lived, with regard to accessing both technical schools and grammars: the intakes to the latter varied from 5 per cent in parts of southern England to 40 per cent in parts of Wales. Contemporary educationalist Fred Clarke was highly critical of the 1944 Act and deeply suspicious of what he described as its:

\begin{abstract}
... class prejudice, and it was fundamentally a social class project, in many ways the culmination of a project, the fulfilment of a vision which was basically that of Matthew Arnold, 80 years before.
\end{abstract}

(cited in McCulloch 2006: 703)

Nonetheless, tripartitism began to slowly lose ground almost as soon as it was established, even though the defence of grammar schools by the Conservative Party and the vague and weak commitment to multilaterals (comprehensives) by the Labour Party led to no clear alternative. As early as 1947, the London School Plan specifically rejected the idea of selection and planned for 64 comprehensive schools, 26 of which were open by 1958 . However, secondary school reorganisation on 'comprehensive' lines was local and patchy, driven by geography, as in Anglesey, the pattern and size of existing schools, as in West Riding, Leicestershire, and Walthamstow, or the degree of aspiring working- and new middle-class discontent with selection processes in many areas. The possibility of your child attending a comprehensive school depended on where you lived.

As noted previously, the 1944 Act also had to grapple again with the 'problem' of church schools and embedded a further compromise over their position as part of the state system:

\footnotetext{
${ }^{16} \mathrm{http} / / / \mathrm{www}$. educationengland.org.uk/documents/norwood/norwood1943.html
} 
The question of the future role of the churches in education proved more complex, more sensitive and more fiercely contested than any other in wartime education reform.

(Barber 1994: 23)

The Act allowed that church schools could become 'controlled' or 'aided'. The former were fully funded and mostly run by LEAs; 6,000 of the 9,000 Anglican schools chose this route, fewer than had been expected. 'Aided' schools retained responsibility for buildings, appointment of teachers and governors, and provision of 'religious instruction', whereas controlled schools followed an 'agreed' religious education syllabus. Many of these 'aided' schools were among those most keen to 'opt out' of LEA control and take up the grant-maintained status offered in the 1988 Education Act.

The bi- or tripartite system and the half-hearted comprehensive reforms that were to follow Circular $10 / 65^{17}$ in many parts of the country-some LEAs took comprehensivism very seriously and others did not (see Ball 1981) —were the outcome of unstable local compromises that were responses to both weak and reluctant central direction and a continuing political reluctance to address the social divisions embedded in existing provision. Nonetheless, in the period between 1966 and 1988, there was a brief comprehensive moment - a moment in part at least bungled and missed by the reluctance of the Labour Party leadership (Chitty 2004). By the time the Labour government did decide to legislate to enforce comprehensive reorganisation, in 1976it was too late. In 1970, Margaret Thatcher, the Secretary of State for Education in the new Conservative government, ended the compulsion on LAs to convert to comprehensive schooling; although more comprehensive schools opened during her time as Secretary of State than any other. The comprehensive moment, such as it was, was decisively brought to an end by the 1988 Education Act (Ball 1990) that laid the foundations of an education market system of education (Ball 1993) or what we might call neoliberal education (Ball 1998).

The education apparatus assembled in England in the 19th century was a product of the first liberalism, a mixture of reluctance, penny-pinching, and necessity (political and economic) driven by a factory-based model of performance management that was payment by results. The contemporary education apparatus is set within the second liberalism (neoliberalism), a mixture of reluctance, penny-pinching, and necessity (political and economic) driven by a factory-based model of performance management that is high-stakes testing, realised in its most pure and immediate form in performancerelated pay for teachers. This is interplayed with doses of neoconservatism and a vision of the curriculum that draws fairly directly from Matthew Arnold and at the same time thoroughly contradicts his vision of the role and purpose of education. ${ }^{18}$

\footnotetext{
${ }^{17} \mathrm{http} / / /$ www.educationengland.org.uk/documents/des/circular10-65.html

${ }^{18}$ In Culture and Anarchy (1869), Arnold argues for the role of reading 'the best that has been thought and said' as an antidote to the anarchy of materialism, industrialism, and individualistic self-interest.
} 


\section{BACK TO THE FUTURE}

So this is where we came in, an educational apparatus, mired in its history, that is diverse and divided, subject over the past thirty years to various forms of supply-side and demand-side deregulation, and predominantly defined publicly and politically by concerns about underperformance. At the same time, partly as a result of deregulation, the number of church schools grew under New Labour (1997-2010) and has grown further within the academies programme. Every third school in England is now a faith school (by contrast, in Scotland the proportion is just 5 per cent). The vast majority are run by the Church of England or the Catholic Church, but there are also now 38 Jewish, 11 Muslim, and four Sikh state schools and several others of other faiths. Currently, the argument for 'faith' schools is based on 'effectiveness' in terms of their relative performance advantage over non-faith schools (although in part at least this can be explained by their intake), as well as parental preference for their so-called 'ethos'. Prime Minister Teresa May, in 2016, also indicated her intention to revisit the past of education in another sense, by creating more grammar schools. Although this failed, at least for the time being, in the face of overwhelming evidence of the grammar school fallacy. As the Education Policy Institute (EPI) noted, ${ }^{19}$ among many other respondents to the government's consultation-Schools that Work for Everyone $^{20}$ - Once prior attainment and pupil background is taken into consideration, we find no overall attainment impact of grammar schools, either positive or negative.' Furthermore, the relatively high performance of these schools 'is driven however by the very high prior attainment and demographics of pupils' and only ' 2.5 per cent of grammar school pupils are entitled to FSM [free school meals], compared with an average of 13.2 per cent in all state funded secondary schools.' The Sutton Trust reported that four times as many of the 22,000 Year Seven entrants into grammar schools each year come from private schools, compared with those on FSMs. ${ }^{21}$ And furthermore the EPI response noted that 'The gap between children on FSM [attaining five $\mathrm{A}^{*}-\mathrm{C}$ GCSEs, including English and Maths] and all other children is actually wider in selective areas than in non-selective areas - at around 34.1 per cent compared with 27.8 per cent.' Prior to this, the government-appointed Chief Inspector of Schools Sir Michael Wilshaw, said grammar schools did nothing to promote social

\footnotetext{
${ }^{19} \mathrm{https}$ //epi.org.uk/publications-and-research/education-policy-institute-response-schools-workeveryone-consultation/

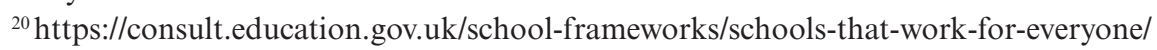

${ }^{21}$ Poor Grammar: Entry into Grammar Schools for Disadvantaged Pupils in England was conducted by researchers at the Institute for Fiscal Studies, Professor Anna Vignoles (the University of Cambridge), and National Centre for Social Research with Professor David Jesson (York University).
} 
mobility, describing them being 'stuffed full of middle-class kids'. ${ }^{22}$ Nonetheless, in May 2018, the DfE announced a $£ 50$ million fund to enable existing grammar schools to establish satellite campuses.

In 2010, the coalition government Secretary of State Michael Gove sought to bring about another major structural change in the English education landscape by offering primary schools the chance to have 'the freedom and the power to take control of their own destiny', as it was put, ${ }^{23}$ and become academies. ${ }^{24}$ Taking this further in the 2016 budget, the Conservative government attempted to bring a kind of coherence to the system in requiring the academisation of all schools. Chancellor George Osborne announced a forced academisation plan, under which all schools in England would either have to convert to academies by 2020 or be committed to converting by 2022. This would have, in effect, ended entirely the link between LAs and schools that began in 1902, but the proposal was quickly abandoned in the face of widespread opposition, including from Conservative MPs and councillors. Ministers indicated that the 'goal' of academising all schools remains, but attention will now focus on schools that are 'clearly failing'.

The reforms that have happened, and those that have not, exacerbate existing incoherences and at the same time issues of both effectiveness and equity remain pertinent and pressing. Research evidence on the performance of academies is confusing and contradictory. For example:

Analysis of GCSE results suggests academies generally do not perform better, but we don't know as much about primary performance..$^{25}$

\footnotetext{
${ }^{22} \mathrm{https}: / / \mathrm{www}$.gov.uk/government/news/annual-report-of-the-chief-schools-adjudicator-for-england, and https://www.telegraph.co.uk/education/educationnews/10518893/Ofsted-chief-grammar-schoolsstuffed-full-of-rich-pupils.html

${ }^{23}$ A CEP report (Eyles \& Silva 2015) on primary academies concludes:

While the international literature provides growing evidence on the effects of school autonomy in a variety of contexts, little is known about the effects of autonomy on primary schools (which are typically much smaller than secondary schools) and in contexts where the school is not deemed to be failing or disadvantaged. The key finding is that schools did change their modes of operation after the exogenous policy change, but at the primary phase of schooling, academisation did not lead to improved pupil performance.

${ }^{24}$ As noted, as of May 2017, 22 per cent of primary schools had taken up this option.

${ }^{25}$ Full Fact: https://fullfact.org/education/academies-and-maintained-schools-what-do-we-know/ (26 May 2017).
} 
The Annual Report of 2015/16 Ofsted commented that:

inspection evidence, research and analysis continues to find that, while becoming an academy can be beneficial for some schools, there is not a clear or substantial difference between the performance of academies and schools maintained by local authorities. ${ }^{26}$

Eyles et al. (2017) found performance in sponsored academies increased more quickly than in similar schools in the mainstream sector. The improvement was greatest in schools that had been academies for the longest, implying that the effect of academy status has a gradual impact on improving performance. Education company SchoolDash found that most primary academies are 'converter' academies, which tended to be high achieving before becoming academies. The research found 'no evidence' that academy status brought improvements to these schools or that such schools were any better than their LA counterparts. The smaller number of 'sponsored' academies, more likely to have been previously underachieving, made more progress when they became academies. ${ }^{27}$

The data suggest that academy sponsorship of 'underperforming' schools can bring about improvements in performance in some cases. Around half of academies are now run by multi-academy trusts. However, significant differences in terms of performance, improvement, and inspection gradings are apparent not simply between academies and non-academy schools, but also between academies, between MATs, and between academies in the same trust. Academy trusts perform more or less well, but some are performing badly enough to have been 'paused' from taking on or opening new schools, although some 'paused' trusts appear to have ignored the ban on taking on or opening new schools, while others have collapsed entirely. In January 2017, 16 sponsors were on the 'paused' list (as shown in Table 1). Three of these trusts have subsequently been wound up, including the Lilac Sky Schools Academy Trust, which handed over nine schools to other trusts in 2016, amid an investigation into their finances and concerns about the low standards at some of its academies:

Academy sponsors banned by the government from taking over new schools seem to have dodged the prohibition.

57 sponsors at different times have been put on the government's 'pause list' and told they cannot take over new schools. Bans remain in place for 16, who between them are responsible for more than 140 schools.

But a Schools Week analysis found some trusts appear to have ducked the ban. The Djanogly Learning Trust, which runs four schools in Nottingham, has been on

\footnotetext{
${ }^{26} \mathrm{https}$ //assets.publishing.service.gov.uk/government/uploads/system/uploads/attachment_data/file/ 574186/Ofsted_annual_report_education_and_skills_201516_web-ready.pdf\#page=122

${ }^{27} \mathrm{http} / / /$ www.bbc.com/news/education-36196665
} 
Table 1. Academy sponsors on DfE 'paused' list.

\begin{tabular}{lr}
\hline Academies Enterprise Trust (AET) & $2012 / 13$ \\
Belvoir \& Melton Academy Trust & $2013 / 14$ \\
Bright Futures Educational Trust & $2015 / 16$ \\
CfBT Education Trust & $2013 / 14$ \\
City of Wolverhampton Academy Trust & $2013 / 14$ \\
Djanogly Learning Trust & $2013 / 14$ \\
Future Schools Trust & $2012 / 13$ \\
Grace Foundation & $2013 / 14$ \\
Hart Schools Trust & $2015 / 16$ \\
Learning Schools Trust & $2013 / 14$ \\
Lilac Sky Academy Trust & $2014 / 15$ \\
Phoenix Multi-Academy Trust & $2013 / 14$ \\
The Education Fellowship Trust & $2013 / 14$ \\
UCAT & $2013 / 14$ \\
Winterhill School & $2015 / 16$ \\
Zail Enterprises Ltd & $2013 / 14$ \\
\hline
\end{tabular}

pause since 2013-14, according to DfE figures. But trust accounts show it 'expanded' when one of its primaries opened a satellite campus for more than 200 pupils in September $2015 .^{28}$

Wakefield City Academies Trust (WCAT), which was paused between 2012-13 and 2013-14 took on 11 more schools, only to announce in September 2017 that it was going to give up all its academies.

Since 2011-12, the government has formally paused the growth of 58 academy trusts, with the expansion of 13 still officially blocked.

Tes has identified a number of trusts that received official warning or pre-warning notices about standards, or financial notices to improve, after having their pause lifted - or that were never formally paused in the first place. ${ }^{29}$

In March 2016, in a letter to the Secretary of State, Chief Inspector of Schools Sir Michael Wilshaw criticised seven major academy chains for failing to improve the results of pupils in their schools, while paying board members large salaries. Speaking about the 2018 PAC Inquiry into the Academy Schools Sector Consolidated Accounts 2015-16, the chair of the committee noted that:

Excessive trustee salaries deprive the frontline of vital funds and it is alarming that, in two-thirds of cases where Government has challenged individual trusts on pay exceeding $£ 150,000$, it has not been satisfied by the response. ${ }^{30}$

\footnotetext{
${ }^{28} \mathrm{https}: / /$ schoolsweek.co.uk/revealed-paused-academy-trusts-are-ducking-their-ban/

${ }^{29} \mathrm{https}: / / \mathrm{www}$. tes.com/news/school-news/breaking-news/inconsistent-approach-academy-growth-showsa-system-out-control

${ }^{30} \mathrm{https} / / / \mathrm{www}$.parliament.uk/business/committees/committees-a-z/commons-select/public-accountscommittee/news-parliament-2017/academy-schools-accounts-report-published-17-19/
} 
Table 2. Percentage of schools of the eight largest MAT chains rated by OfSTED as 'outstanding/good' or 'requires improvement/inadequate'.

\begin{tabular}{llll}
\hline Chain & Number of schools & Outstanding/good & $\begin{array}{l}\text { Requires improvement } \\
\text { /inadequate }\end{array}$ \\
\hline Academies Enterprise Trust & 66 & $56 \%$ & $36 \%$ \\
United Learning & 41 & $51 \%$ & $21 \%$ \\
Reach 2 & 50 & $16 \%$ & $16 \%$ \\
TKAT & 41 & $46 \%$ & $41 \%$ \\
Oasis & 45 & $36 \%$ & $42 \%$ \\
Plymouth CAST & 35 & $3 \%$ & $0 \%$ \\
School Partnership Trust & 43 & $44 \%$ & $37 \%$ \\
David Ross & 33 & $36 \%$ & $27 \%$ \\
Total & 354 & & \\
\hline
\end{tabular}

As of March 2016, the eight largest MATs ran a total of 354 schools. The percentage of schools of the eight largest chains rated by Ofsted as 'outstanding/ good' or 'requires improvement/inadequate' was as shown in Table 2. In June 2018, EPI published an analysis of the best and worst performing MATs and LAs. Schools Week reported that:

It found that local authorities make up 15 of the top 20 school groups at key stage two, with just one MAT - the Harris Federation - making it into the top 10. Academy chains are 'disproportionately represented amongst the lowest performing groups', with 12 making it into the bottom 20 .

Fourteen of the top 20 performing secondary school groups are academy chains, and just one of the six top performing local authorities is not in London. Although the bottom 20 is more even, three of the worst four are academy chains, including the Education Fellowship Trust, which gave up all 12 of its schools in March 2017, and Bright Tribe Trust, which relinquished all but one of its northern schools this year. ${ }^{31}$

We might conclude from all of this that in the terms set by all governments since 1988, the changes that have been wrought upon schools in this period have shifted from a system with disparities, in relation to their intake and performance, between schools of different sorts run by LAs, the majority of these being what Alastair Campbell called 'bog standard comprehensive schools', to a much more complicated system of different sorts of schools, delivered by a range of different providers, with marked disparities between schools in relation to their intake and performance.

\footnotetext{
${ }^{31}$ https://schoolsweek.co.uk/epi-report-best-and-worst-performing-academy-trusts-and-las-revealed/
} 


\section{FUZZINESS AND (DIS)ADVANTAGE}

These variations in provision and performance add further complexity to an already fuzzy, segmented market, that is difficult for many parents to navigate, which calls up tactical behaviour, and on occasion deception and bad faith - on both sides (choice on the one hand and recruitment on the other-as suggested earlier). The education market is rife with gaming (Foley \& Goldstein 2012), and allows agile and well-resourced middle-class parents to seek out and maintain social advantage in educational settings where there are others 'like them' (Ball \& Vincent 1998).

Differences between schools in terms of both intake and relatedly performance are maintained, and reinforced by an economy of student worth that gives high value to those from homes with supportive and informed parents and with high prior attainment and, where they are able, schools will seek to recruit such students. And low value to others, with special educational needs (SEN) or histories of behavioural difficulty, low prior performance, or English as a second language, ${ }^{32}$ who are avoided if possible. This economy generates multiple forms of social segregation (Allen \& Parameshwaran 2016).

Our analysis looks at the extent to which schools disproportionately exclude poorer pupils after taking into account the level of poverty in their areas. In certain types of schools there seems to be a tension between choice and social cohesion. Living close to a school doesn't always translate into being able to send your child there. Some outlier schools have intakes that are wildly different from the local population mix. We need to ask why that is.

(Timo Hannay, founder of education data analysis company SchoolDash) ${ }^{33}$

The analysis done by SchoolDash also found that:

A family living next to a school rated 'Inadequate' by Ofsted is over $60 \%$ more likely to be poor than one living next to an 'Outstanding' school.

Poor children seem to cluster in particular schools due to a combination of demographic and school selection effects-and if anything it is the latter that has the larger impact. The schools most available to them are sponsor-led academies or those with poor Ofsted ratings. When it comes to admitting poorer pupils, faith schools tend to be either neutral or negative. ${ }^{34}$

\footnotetext{
${ }^{32}$ This may be changing, data released (18 January 2018) by the DfE show that children who grow up speaking a language other than English now have a higher attainment score than their native-speaking peers by the time they are 16 .

${ }^{33}$ Quoted in: https://www.theguardian.com/education/2016/aug/02/school-widen-poverty-admissionsacademy-free-schools-segregation

${ }^{34}$ https://www.schooldash.com/blog-1608.html\#20160802
} 
Looking, very briefly, across the system as a whole, the government argues, contentiously in the view of many commentators, that their data indicate improvements over time, and that achievement 'gaps' are being closed as a direct result of government policies. Schools Minister Nick Gibb explained to teachers attending an international conference in March 2018 that:

Free schools are amongst some of the highest performing schools in the country and pupils in free schools made more progress, on average, than pupils in other types of school in 2017.

Dixons Trinity Academy — a free school based in Bradford — achieved extraordinary results with its first set of GCSEs, placing it in the 10 top schools in England for the progress achieved by its pupils. Strikingly, the progress score for disadvantaged pupils was higher than for that of their more affluent peers.

But the success of the free school and academy movement is not confined to individual schools. The growth of multi-academy trusts has seen excellence spread across schools. Multi-academy trusts are combinations of academies, from 2 or 3 , to as many as 50 or 60 academies, all reporting to one group of independent trustees. ${ }^{35}$

And on National Primary Offer Day: 16 April 2018:

This morning, thousands of pupils and their parents will find out which primary school they will be going to this September. Thanks to our reforms and the hard work of teachers, academic standards in our primary schools are rising across the country. Our young readers are among the best in the world, the proportion of primary school pupils reaching the expected standards in reading, writing and maths standards went up 8 percentage points last year and the attainment gap between children from wealthier and poorer backgrounds has narrowed by $10.5 \%$ since $2011 .{ }^{36}$

However, a 2015 report by the House of Commons Education Committee, entitled Free Schools and Academies, ${ }^{37}$ recommended 'that the Government should stop exaggerating the success of academies and be cautious about firm conclusions except where the evidence merits it. Academisation is not always successful nor is it the only proven alternative for a struggling school' (House of Commons Education Committee 2015).

In many respects it would be surprising if there were not performance improvements in a system that is focused primarily on performance outcomes ${ }^{38}$ and teaching to the

\footnotetext{
${ }^{35} \mathrm{https} / / /$ www.gov.uk/government/speeches/nick-gibb-welcomes-teachers-to-international-conference

${ }^{36} \mathrm{https}: / /$ www.gov.uk/government/news/national-primary-offer-day?utm_source=f412362f-2c78-4879ad19-.0cb87bb7624c\&utm_medium=email\&utm_campaign=govuk-notifications\&utm_content=immediate

${ }^{37} \mathrm{https} / / /$ schoolsweek.co.uk/epi-report-best-and-worst-performing-academy-trusts-and-las-revealed/ http://www.publications.parliament.uk/pa/cm201415/cmselect/cmeduc/258/258.pdf

${ }^{38}$ DfE figures released 18 January 2018 indicate that rising numbers of secondary schools are considered underperforming, meaning they fall below the 'floor standard'. The DfE argues that the rise in
} 
test in many forms,$^{39}$ but certain basic features of the unevenness of the pre-reform performance landscape remain unchanged (Reay 2017). The Institute for Government Performance Tracker report ${ }^{40}$ concludes that OECD PISA (Programme for International Student Assessment) and TIMSS (Trends in International Mathematics and Science Study) surveys of educational performance suggest that the quality of education in England generally_ in terms of students' knowledge and skills in mathematics, reading, and science- has not risen, but remained broadly flat in recent years. Drawing on the National Pupil Database, a 2017 EPI research report notes that:

The attainment gap between the most and least disadvantaged children persists, although it has narrowed since 2009. Nonetheless, in 2016, pupils from disadvantaged backgrounds - defined as children who had been eligible for free school meals at any point in the previous six years - were on average 18.9 months behind the rest of their peers at the end of secondary school, in terms of their relative progress.

At this rate, the report concludes, it would take fifty years to close the attainment gap between England's most disadvantaged pupils and their wealthier peers (Andrews et al. 2017). ${ }^{41}$

Whatever 'improvements' are claimed, the educational apparatus in England continues to be decisively marked by very clear relations between performance and social class, and poverty and access, and social class and poverty. In a report published in April 2018, Teach First noted that:

Across England, nearly one in three $(29 \%)$ children who start primary school aged five are assessed as not having a sufficient level of development to be 'school ready'.

But the figures vary dramatically between regions and communities. Four in ten children are not school ready in Liverpool (38\%) and Halton (39\%). However, this falls to just two in ten in Lewisham (21\%), Greenwich (22\%) and Richmond upon Thames (22\%).

And poorer children in every area of the country are more likely to start school behind their wealthier peers. Across the country, just under half $(44 \%)$ of poorer children (those eligible for Free School Meals) are not 'school ready' by the time they start primary school. This compares to just over a quarter (27\%) of wealthier pupils (not eligible for Free School Meals). ${ }^{42}$

underperforming schools is because of technical changes to the points system used by government statisticians to calculate a school's performance.

${ }^{39}$ Leaving aside the impoverishments to the educational experience that this may engender.

${ }^{40} \mathrm{https}: / / \mathrm{www}$.instituteforgovernment.org.uk/publication/performance-tracker-autumn-2017/schools

${ }^{41} \mathrm{https}: / /$ epi.org.uk/wp-content/uploads/2017/07/closing-the-gap-web.pdf

${ }^{42} \mathrm{https} / / /$ www.teachfirst.org.uk/node/2076 
However, the report goes on to argue that:

The charity's analysis shows that teachers and schools can overcome this disadvantage. Some areas with the most unequal intake show remarkable progress for their poorest children by the end of Key Stage 1, when children are seven years old.

Some of these relations of social class to schooling are reminiscent of those of the 19 th century. Others are new, but clearly patterns of performance vary according where you live. Young people from different social backgrounds are spread unevenly across the landscape of provision, and experience the market forces which operate across it differently. The resulting social divisions and social exclusions are multiple and multifaceted, gross and subtle, intended and unintended, and often poorly understood or simply unattended to by policy (save perhaps with the exception Sure Start ${ }^{43}$ and Education Maintenance Allowances (EMAs) ${ }^{44}$ ). This uneven multifacetedness of inequities is difficult to grasp and describe. I will note as illustration, from among many others, five very different consequences or dimensions of market freedoms, of gaming and of geographical variation.

1. One in five students in independent schools received extra time to complete GCSE and A-level exams in 2017 compared with fewer than one in eight in state schools. (An analysis of official exam data by BBC Radio 4's 'Today' programme). ${ }^{45}$

2. Black Caribbean boys remain four times as likely to be excluded from school as White British boys, and Black Caribbean girls are twice as likely to be excluded as their White British counterparts. A Black Caribbean boy in receipt of FSM and with SEN is 168 times more likely to be permanently excluded than a White British girl without SEN. Children who are in care or are known to social services are two to three times as likely to be excluded as those who are not, and those who are eligible for FSM due to low income have four times the risk of other children. As well as ethnic factors and SEN, rates of exclusion are elevated for children from deprived backgrounds, those with family problems, mental health and social communication difficulties, low test scores, or experiences of bullying. ${ }^{46}$ Eight out of the ten areas with the highest exclusion rates in England are in the North East,

\footnotetext{
${ }^{43}$ Sure Start is a UK government area-based initiative, announced in 1998 by the then Chancellor of the Exchequer, Gordon Brown, The initiative originated from HM Treasury with the aim of 'giving children the best possible start in life' through improvement of childcare, early education, health, and family support, with an emphasis on outreach and community development.

${ }^{44} \mathrm{EMA}$ is a financial scheme applicable to students and those undertaking unpaid work-based learning in Wales, Scotland, and Northern Ireland and aged between 16 and 19 whose parents had a certain level of taxable income. It is no longer paid in England.

${ }^{45} \mathrm{http}: / /$ www.bbc.com/news/education-38923034

${ }^{46} \mathrm{https}$ ://epi.org.uk/publications-and-research/many-vulnerable-children-excluded-school/
} 
and Yorkshire and the Humber. ${ }^{47}$ The chances of your child being excluded from school depend on your ethnicity and where you live.

3. Free school places are more likely to be found in areas of high performance (such as London) than in the areas of low school performance (such as the North East). Free schools located in areas of disadvantage are less likely to admit disadvantaged pupils from these areas. ${ }^{48}$

4. Schools with a religious denomination can be shown to have a more able and affluent intake than community comprehensives, especially once the characteristics of the local neighbourhood are taken into account. This means that areas with many religious schools have higher levels of school segregation. ${ }^{49}$

5. The intake into sponsored academies has consisted of a lower proportion of pupils from relatively deprived backgrounds and converter academies may not be taking advantage of aspects of independence from local LA control, coupled with a continued pursuit of high performance outputs, to adapt their admissions (and exclusions policies) to achieve a more homogeneous and advantageous pupil intake. $^{50}$

The educational apparatus of England is a patchwork of geographically and socially uneven provision and performance, compounded and cross cut with multiple divisions and exclusions, and permeated by opportunities for advantage seeking.

\section{THE MEDDLESOME STATE}

Alongside competition, institutional freedoms, and diversity, and odd combinations of innovation and tradition, the educational apparatus is currently animated and inundated by a bewildering and reactive form of 'policy hyperactivity' - mostly aimed at raising performance, but including an array of other 'priorities'. These are driven by ministerial enthusiasms and biases, international orthodoxies, and ad hoc and often ill-informed and ill-thought-out borrowings from other systems (Morris 2012). Despite the deregulation of provision and greater institutional freedoms offered to some schools, all schools are subject to targeted, systemic and partial, disparate and uncoordinated, and repetitive interventions from government. Some examples of recent 'fixes' and initiatives are shown in Table 3. Schools are being expected to be both innovative and conservative, to deliver social mobility and social cohesion,

\footnotetext{
${ }^{47} \mathrm{http}: / /$ www.bbc.co.uk/news/uk-england-43112324

${ }^{48} \mathrm{https}$ ://epi.org.uk/publications-and-research/free-schools-england/

${ }^{49} \mathrm{https} / / /$ rebeccaallen.co.uk/2008/02/27/admissions-to-faith-schools-in-england/

${ }^{50} \mathrm{https} / / / \mathrm{www} . \mathrm{nfer}$.ac.uk/publications/IMPB02/IMPB02.pdf
} 
Table 3. A list of some policies announced by DfE June 2017-February 2018.

Multi-Academy Trust Development and Improvement Fund(MDIF)

Strategic School Improvement Fund (SSIF)

Social mobility action plan announced, Unlocking Talent, Fulfilling Potential

12 Opportunity Areas

Essential Life Skills programme

Evidence Champion for the Opportunity Areas appointed

Teacher Development Premium introduced

New National Centre for Computing

The Mathematics Teacher Exchange

Character Grant programme replaced with $£ 22$ million to fund the development of essential life skills in children and young people in the twelve Opportunity Areas

A new Centre of Excellence for Literacy Teaching that will set up a national network of 35 English Hubs across the country, mirroring the Maths Hubs

April 2018, new phonics and reading partnerships; phonics and reading roadshows

$£ 5.7$ million through the Strategic School Improvement Fund for initiatives that boost literacy and numeracy skills

Inviting organisations to bid for the contract to launch a $£ 5$ million fund to trial approaches across the North of England that will help parents and carers to support early language development at home

A new $£ 7.7$ million curriculum fund - delivering on a manifesto commitment - to encourage the development of high-quality teaching resources by organisations, including by leading cultural and scientific institutions

DfE-Plan to boost social mobility through the plan Unlocking Talent, Fulfilling Potential will deliver targeted action where it is needed most, focusing $£ 800$ million of (previously announced) government investment on places and communities across the country that feel they have been 'left behind'

Measures include $£ 50$ million for schools to open new nursery places and $£ 23$ million for a 'Future Talent Fund', which is aimed to supporting bright students from poorer backgrounds

improve cognitive and non-cognitive skills, to be collaborative and entrepreneurial. There is centralisation and fragmentation at the same time; there is deregulation, deconcentration, and intervention at the same time. The state acts as both gardener and gamekeeper (Urry 2000) - that is, it employs both direct and indirect forms of control, both prescription and direction, and contracting out and performance management - another kind of incoherence. In the midst of this hyperactivity, policy begets policy as new 'solutions' are generated to respond to the failures, inadequacies, and inefficacies of previous fixes. ${ }^{51}$ Schools must make sense of, respond to, and enact (or not) (Braun et al. 2010) a constant barrage of new initiatives, funding streams, and regulations alongside continually changing measures, indicators, targets, and

\footnotetext{
${ }^{51}$ See Foucault (1997).
} 
benchmarks, all of which contribute to increasing workloads (Sellen 2016). According to the OECD's latest Teaching and Learning International Survey (TALIS) (OECD 2014) full-time teachers In England work an average of 48.2 hours per week - the third highest out of 35 jurisdictions compared, 19 per cent longer than the average elsewhere. Currently, unsurprisingly, in good part as a result of policy hyperactivity, more teachers are leaving the system than are being recruited, and recruitment targets are being missed. In 2016, the equivalent of 10.4 per cent of the secondary teaching workforce left state school teaching. The number of teachers going 'out of service' (that is, not retiring) rose from 25,260 in 2011 to 34,910 in 2016, a 38 per cent increase. ${ }^{52}$ As with recruitment, retention issues do not fall equally across the subjects. Science, maths, and language teachers have higher than average leaving rates in the first few years after training - despite the higher bursaries offered to trainees. Furthermore, teachers, in terms of experience and specialisms, are spread increasingly unevenly across the country and between types of schools, as are the rates of teacher turnover. The chance of having and keeping a wellqualified or experienced teacher or specialist in a shortage subject to teach your child depends on where you live. ${ }^{53}$

This brings us to the question of the definition and location of policy problems. The focus of policy attention in relation to the 'problem' of student performance and performance 'gaps' is firmly on the school. However, a great deal of research, from many different sources, indicates that schools account for only a minority part of the explanation of the variance of performance between students (Wilkinson et al. 2018); although individual teachers can be considerably more important (see below).$^{54}$

The current headline pupil attainment indicator, Progress 8, which is used in the current school league tables, compares attainment at the end of primary schooling with attainment at the end of compulsory schooling, typically at age 16 , so tracks the progress of pupils. We find that in 2015/16 schools explain 14 per cent of the pupillevel variation in Progress 8. Part of this 'school effect' is related to the similarity of pupils within schools, so that pupils with characteristics associated with better or worse attainment cluster in schools. Our analysis shows that controlling for the

\footnotetext{
${ }^{52}$ See https://epi.org.uk/publications-and-research/teacher-workload-professional-development-englandssecondary-schools-insights-talis/ and Foster (2018).

${ }^{53}$ In its annual report (November 2017) The Social Mobility Commission noted that schools in deprived areas often struggle to recruit teachers and often lack high-quality applicants. Secondary teachers in deprived areas are also most likely to leave. There is much more stability in affluent areas (Social Mobility Commission 2017: 46-7; 53).

${ }^{54} \mathrm{https}: / /$ www.suttontrust.com/wp-content/uploads/2011/09/2teachers-impact-report-final.pdf and http://ftp.iza.org/dp1459.pdf
} 
similarity of pupils in schools, schools account for around 9 per cent of variance in pupils' attainment. ${ }^{55}$

By far the greater part of variance in student attainment is explained by factors related to social background, ${ }^{56}$ and poor performance is strongly related to the conditions of family life and problems of poverty, ${ }^{57}$ poor nutrition, homelessness, and unemployment, but also to levels of parental education and aspiration and support. In this sense it would be reasonable to argue that education policy is looking at and working on the wrong place and is bound to fail if the socio-economic conditions of students' home lives remain dramatically unequal.

What we end up with is the worst of several worlds - a mix of de-concentration and intervention, which manifest ever more complex forms of segregation and inequality, while delivering an impoverished curriculum, ${ }^{58}$ to children who are increasingly stressed by the demands of performance, many of whom experience low levels of individual well-being, ${ }^{59}$ without any clear sense of purpose and value, other than that which can be calculated from test scores and examination grades. To reiterate, this apparatus bears more than a passing resemblance to the system pre-1870, inasmuch that there are costs (direct and indirect) ${ }^{60}$ to parents, issues of uneven attendance (or exclusion), marked regional variations, and a diversity of providers working

\footnotetext{
${ }^{55} \mathrm{See}$ https://www.niesr.ac.uk/blog/how-much-do-schools-matter and http://archive.treasury.gov.au/ documents $/ 1421 / \mathrm{HTML} /$ docshell.asp?URL $=05 \% 20 \mathrm{How} \% 20$ much $\% 20$ of $\% 20$ the $\% 20$ variation $\% 20$ in $\% 20$ Literacy $\% 20$ and $\% 20$ Numeracy $\% 20$ can $\% 20$ be $\% 20$ explained $\% 20$ by $\% 20$ School $\% 20$ Performance. htm

${ }^{56} \mathrm{http} / / /$ risetrust.org.uk/pdfs/EReview-4.pdf

${ }^{57}$ There were 4.1 million children living in poverty in the UK in 2016-17. That is 30 per cent of children, or nine in a classroom of thirty (http://www.cpag.org.uk/child-poverty-facts-and-figures).

${ }^{58}$ Students' access to physical education, art, music, and drama lessons, as two recent surveys have shown, has declined overall, varies between schools, and will depend on where you live. See http://www.bbc.com/ news/education-42862996. Research carried out by the Youth Sport Trust found that 38 per cent of English secondary schools have cut timetabled physical education for 14-16-year-olds since 2012, while almost one in four (24 per cent) have done so in the last academic year. (https://www.youthsporttrust.org/ news/research-finds-whistle-being-blown-secondary-pe)

${ }^{59}$ A 2015 Children's Society study, which looked at fifteen diverse countries, found that children in England to be among the unhappiest in the world, behind countries such as Ethiopia, Algeria, and Romania. England ranked fourteenth for life satisfaction of its young people, ahead of South Korea. (https://www.childrenssociety.org.uk/sites/default/files/TheGoodChildhoodReport2015.pdf)

${ }^{60}$ A survey by the NASUWT: The Teachers' Union conducted in 2017 based on almost 4,000 responses found that almost one in five parents in the UK is being asked to set up payments to their children's schools; 18 per cent of parents have been asked to sign up for direct debits or standing orders for their children's school, typically of about $£ 50$ per year; more than one in twenty parents with children in state schools were paying $£ 400$ or above; a further 13 per cent of parents had been asked to make donations in cash or cheques. (https://www.nasuwt.org.uk/article-listing/access-education-increasingly-parents-abilitypay.html)
} 
within a system of 'payment by results'. There is a new patchwork, full of gaps across which churches and philanthropists are major providers.

\section{THINKING EDUCATION POLICY DIFFERENTLY}

I have tried to convey here a sense of the irrationality, unevenness, and unfairness of the current arrangements for schooling in England. I have argued that these arrangements have come about through a combination of reluctance and over-zealousness on the part of the educational state, and reflect and reproduce the interests of middle-class parents and church school providers and entrench patterns of social disadvantage. I have described various ways in which access to types of school and educational experience depends on where you live and who you are. I have characterised the educational state as both wedded to a discredited past and as failing to understand and address the relation between school performance and the social conditions of family life.

Nonetheless, within the apparatus adumbrated above, some schools and many teachers are doing a good job for their students, working long hours to offer as far as they are able a rounded educational experience in ways that are fair and equitable, but I would suggest this is more often than not in spite of rather than because of policy. ${ }^{61}$ And in the heat and noise of reform, of initiatives and fixes and of 'what works', the issue that is neglected or ignored, or simply just pre-empted within the processes of reform, is 'what for'. Any sense of the values of education is lost in the maze of policy hyperactivity, and goals and purposes are foregone by the demands of fast policythat is, processes of intensification and compression, new ideas, fads, and fashions moving at social-media speed (Peck \& Theodore 2015). What counts as education is in the current policy context, to a great extent, formed and produced by its measurement - that is, quality in education is defined in terms of performance, and what are referred to as educational standards are rendered as performance outputs. 'Values are embodied in the various activities and techniques available to education, techniques that instrumentalise our hopes, fears, vulnerabilities and emotions' (Allen 2017: 96). The values, commitments, and professionalism of teachers are displaced by forms of technical expertise and the celebration of technocratic solutions to social and political problems; what matters is not what is educationally meaningful, but 'what works'. Educational substance is reduced to indicators or outputs. The teacher is defined by

${ }^{61}$ It is tempting to suggest that this is not so much incoherence as absurdity - creating an impossible tension for many in education between 'the mind that desires and the world that disappoints' (Camus 1955: 37). 
and tied to systems of performance-related pay and positioned as part of what Barber (2007) calls the delivery chain and its necessarian logic; that is, hierarchies of expectation that connect frontline service delivery to the responsible minister by ensuring a sharp focus on performance priorities (rather than purposes or substance). In relation to all of this, there is an absence of public settings and opportunities in which matters of values and purpose can be meaningfully debated and in some way or other, and as appropriate, related to practice. This is not just a question of the airing of their views by politicians, or academics, or teachers, but also by parents, students, and employers - over and against the behemoth of performance.

How might this change? In pragmatic terms what is needed is a process of restarting policy from a different set of organising principles - and concomitantly a staged but unequivocal abandonment of the current education policy infrastructure. Ways must be found to eradicate the damage done to the creativity, well-being, and enthusiasm of teachers and students by the regime of performativity (Ball 2003). This would mean detaching education from the distortions of measurement and comparison, converting them 'from exam factories to communities of discovery' (Coffield \& Williamson 2011). The political process of rethinking education for the 21 st century, related to real social needs and economic problems, those embedded in the everyday world of families and communities, will only come about, I would argue, by unleashing the innovative potential of schools, teachers, and parents, by building and exploiting a proper sense of 'democratic fellowship' (Fielding \& Moss 2011), and by rebuilding trust in teachers and schools. Essentially, tackling the relationship between education, inequality, and poverty differently would involve re-connecting the processes and experience of education with the lives, hopes, and aspirations of all children and all parents, not through choice and competition but through participation, debate, and the educative engagement of schools with their communities.

\section{REFERENCES}

Allen, A. (2017), The Cynical Educator (Leicester, Mayfly).

Allen, R. \& Parameshwaran, M. (2016), Caught Out: Primary Schools, Catchment Areas and Social Selection (London, Sutton Trust). http://www.suttontrust.com/wp-content/uploads/2016/04/ Caught-Out_Research-brief_April-16.pdf.

Allen, R., Burgess, S. \& McKenna, L. (2014), School Performance and Parental Choice of School: Secondary Data Analysis (London, Department for Education). https://assets.publishing.service. gov.uk/government/uploads/system/uploads/attachment_data/file/275938/RR310_-_School_ performance_and_parental_choice_of_school.pdf

Andrews, J., Robinson, D. \& Hutchinson, J. (2017), Closing the Gap: Trends in Educational Attainment and Disadvantage (London, Educational Policy Institute).

https://epi.org.uk/publications-and-research/closing-gap-trends-educational-attainment-disadvantage/ 
Arnold, M. (1869) Culture and Anarchy (London, Smith, Elder).

Ball, S. J. (1981), Beachside Comprehensive: A Case Study of Secondary Schooling. (Cambridge, Cambridge University Press).

Ball, S. J. (1990), Politics and Policymaking in Education (London, Routledge).

Ball, S. J. (1993), The Education Reform Act: Market Forces and Parental Choice', in A. Cashdan \& J. Harris (eds) Education in the 1990s (Sheffield, Pavic Publications).

Ball, S. J. (1997), 'Policy Sociology and Critical Social Research: A Personal Review of Recent Education Policy and Policy Research', British Educational Research Journal, 23: 257-74. https://doi.org/10.1080/0141192970230302

Ball, S. J. (1998), 'Ethics, Self Interest and the Market Form in Education', in A. Cribb (ed.) Markets, Managers and Public Service?, Occasional Paper No. 1. Centre for Public Policy Research, King's College, London.

Ball, S. J. (2003), 'The Teacher's Soul and the Terrors of Performativity', Journal of Education Policy, 18: 215-28. https://doi.org/10.1080/0268093022000043065

Ball, S. J. \& Junemann, C. (2012), Networks, New Governance and Education (Bristol, Policy Press). https://doi.org/10.1332/policypress/9781847429803.001.0001

Ball, S. J. \& Vincent, C. (1998), " "I Heard it on the Grapevine": "Hot" Knowledge and School Choice', British Journal of Sociology of Education, 19: 377-400. https://doi.org/10.1080/0142569980190307

Barber, M. (1994), The Making of the 1994 Education Act (London, Cassell).

Barber, M. (2007), Instruction to Deliver: Tony Blair, the Public Services and the Challenge of Delivery (London, Methuen).

Barnett, C. (1986), The Audit of War (London, Macmillan).

Best, G. \& Andrew, F. (1972), Mid-Victorian Britain 1851-1875 (London, Schocken Books).

Braun, A., Maguire, M. M. \& Ball, S. J. (2010), 'Policy Enactments in the UK Secondary School: Examining Policy, Practice and School Positioning', Journal of Education Policy, 25: 547-60. https://doi.org/10.1080/02680931003698544

Camus, A. (1955), The Myth of Sisyphus and Other Essays (New York, Alfred A. Knopf).

Chitty, C. (2004), Education Policy in Britain (Basingstoke, Palgrave Macmillan).

Coffield, F. \& Williamson, B. (2011), From Exam Factories to Communities of Discovery (London, IOE Press).

Eyles, A. \& Silva, O. (2015), 'Academies 2: The New Batch', discussion paper 1370, Centre for Economic Performance, London School of Economics and Political Science, London.

Eyles, A., Machin, S. \& McNally, S. (2017), 'Unexpected School Reform: Academisation of Primary Schools in England', Journal of Public Economics, 155 (November): 108-121. https://doi.org/10.1016/j.jpubeco.2017.09.004

Fielding, M. \& Moss, P. (2011), Radical Education and the Common School: A Democratic Alternative (London, Routledge).

Foley, B. \& Goldstein, H. (2012), Measuring Success: Leagues Tables in the Public Sector (London, British Academy). https://www.britac.ac.uk/sites/default/files/BRI1429_league_tables_report_03\%2012_web.pdf

Foster, D. (2018), Teacher Recruitment and Retention in England, Briefing Paper 7222, House of Commons Library, London. researchbriefings.files.parliament.uk/documents/CBP-7222/CBP-7222.pdf

Foucault, M. (1997), 'Polemics, Politics and Problematizations: An Interview Conducted by Paul Rabinow in May 1984', translated by L. Davis, in Essential Works of Foucault: Volume 1 Ethics (New York, The New Press).

Hoppen, K. T. (1998), The Mid-Victorian Generation 1846-1886 (Oxford, Oxford University Press). 
House of Commons Education Committee (2015), Academies and Free Schools: Fourth Report of Session 2014-15 HC 258, (London, TSO).

https://publications.parliament.uk/pa/cm201415/cmselect/cmeduc/258/258.pdf

McCulloch, G. (2006), 'Education and the Middle Classes: The Case of English Grammar Schools, 1868-1944', History of Education, 35: 689-704. https://doi.org/10.1080/00467600600967585

Mitch, D. (2016), 'Schooling for All Via Financing by Some: Perspectives from Early Modern and Victorian England', Paedagogica Historica: International Journal of History of Education, 52: 325-48. https://doi.org/10.1080/00309230.2016.1178783

Morris, P. (2012), 'Pick 'n' Mix, Select and Project; Policy Borrowing and the Quest for "World Class" Schooling: An Analysis of the 2010 Schools White Paper', Journal of Education Policy, 27: 89-107. https://doi.org/10.1080/02680939.2011.596226

OECD (2014), TALIS 2013 Results: An International Perspective on Teaching and Learning (Paris, OECD).

Ozga, J. (1990),"Policy Research and Policy Theory: A Comment on Fitz and Halpin”, Journal of Education Policy, 5: 359-62. https://doi.org/10.1080/0268093900050405

Peck, J. \& Theodore, N. (2015), Fast Policy. Experimental Statecraft at the Thresholds of Neoliberalism (Minneapolis, MN, University of Minnesota Press).

https://doi.org/10.5749/minnesota/9780816677306.001.0001

Perkin, H. (1969), The Orgins of Modern Society, 1780-1880 (London, Routledge).

Reay, D. (2017), 'The State Education Is In: Recognising the Challenge of Achieving a Fair Educational System in Post-Brexit, Austerity England', Forum, 59: 325-30. https://doi.org/10.15730/forum.2017.59.3.325

Sellen, P. (2016), Teacher Workload and Professional Development in England's Secondary Schools: Insights from TALIS (London, Educational Policy Institute).

https://epi.org.uk/wp-content/uploads/2018/01/TeacherWorkload_EPI.pdf

Simon, B. (1994), The State and Educational Change: Essays in the History of Education and Pedagogy (London, Lawrence and Wishart).

Skelcher, C. (1998), The Appointed State (Buckingham, Open University Press).

Skelcher, C. (2000), Changing Images of the State-Overloaded, Hollowed-out, Congested', Public Policy and Administration, 15(3): 3-19. https://doi.org/10.1177/095207670001500302

Social Mobility Commission (2017), State of the Nation 2017: Social Mobility in Great Britain (London, Social Mobility Commission). https://assets.publishing.service.gov.uk/government/uploads/ system/uploads/attachment_data/file/662744/State_of_the_Nation_2017_-_Social_Mobility_in_ Great_Britain.pdf

Tawney, R. H. (1931), Equality (London, George Allen \& Unwin).

Timmins, N. (2001), The Five Giants: A Biography of the Welfare State, new edition (London, HarperCollins).

Urry, J. (2000), Sociology Beyond Societies: Mobilities for the Twenty-first Century (London, Routledge).

Webb, P. T. (2014), 'Policy Problematization', International Journal of Qualitative Studies in Education, 27: 364-76. https://doi.org/10.1080/09518398.2012.762480

Wilkinson, D., Bryson, A. \& Stokes, L. (2018), 'Assessing the Variance in Pupil Attainment: How Important is the School Attended?', National Institute Economic Review, 243(1): 4-16.

https://doi.org/10.1177/002795011824300110 
Note on the author: Stephen J. Ball is Distinguished Service Professor of Sociology of Education at the Institute of Education, University College London. He was elected Fellow of the British Academy in 2006; and is also Fellow of the Society of Educational Studies, and a Laureate of Kappa Delta Phi. He is co-founder and Managing Editor of the Journal of Education Policy. Recent books include The Education Debate (Policy Press, 2017), Foucault as Educator (Springer, 2017) and Edu.Net (Routledge 2017). stephen.ball@ucl.ac.uk

To cite the article: Stephen J. Ball (2018), 'The tragedy of state education in England: Reluctance, compromise and muddle - a system in disarray', Journal of the British Academy, 6: 207-00.

DOI https://doi.org/10.85871/jba/006.207

This article is licensed under a

Creative Commons Attribution-NonCommercial-NoDerivs 3.0 Unported License.

Journal of the British Academy (ISSN 2052-7217) is published by

The British Academy - the national academy for the humanities and social sciences. 10-11 Carlton House Terrace, London, SW1Y 5AH

www.britishacademy.ac.uk 